\title{
The Implementation of Teachers' Pedagogical and Professional Competence in Authentic Assessment
}

\author{
Annisa Faizah ${ }^{\bowtie}$, Djoko Sutopo \\ Universitas Negeri Semarang, Indonesia
}

\begin{abstract}
Article Info
Article History:

Article History:

Recived 28 July 2021

Accepted 3 October

2021

Published 23

December 2021

Keywords:

English teachers, professional, pedagogical competence, assessment

Abstract

This study aims to explain the teacher's pedagogical competence and professional competence on EFL, authentic assessment on EFL, describe the application of authentic assessment, and investigate the effect of teachers' pedagogical and professional competencies on authentic assessment practice. This qualitative study investigated the effects of pedagogical and professional competencies on authentic assessment practice. The subjects of the study consisted of the English teachers of Public Senior High School 1 Jepara. The data were collected with the observation checklist, questionnaire, and interview. The data were analyzed with Miles and Huberman's model. The teacher manifested her pedagogical competence into the plan implementation, evaluation, and reflection. The way she applied authentic assessment was only with the project. She was aware of the function of authentic assessment. It was proven that she did not level up the learning activities when the learners had not passed a specific criterion she determined. However, since she did not provide corrective feedbacks, the learners felt that the teacher only assessed the final project product. Moreover, the teacher did not provide a proper evaluation. She only provided the correct examples, so it made the learners could not arrange their plans. This situation could be improved if the teacher continuously developed her academic qualification and competence based on science, technology, and artistic advancement. Teachers should have this features to be more professional.
\end{abstract}




\section{INTRODUCTION}

Assessment is an essential element in learning. The reasons are - assessment allows teachers to know the process and learning outcomes achieved by students (Atmazaki, 2017). In the 2013 Curriculum, authentic assessment is a tool for the teacher to evaluate or assess the students. Because of its differences from the earlier evaluation tool, some teachers are still confused about using it. Moreover, the teachers have difficulties in applying it (Atmazaki, 2017).

Authentic assessment is a complex and demanding process, but it is vital for educational reforms in assessment (Azim\&Khan, 2012). Specifically, concerning student education, the task itself, and the process undertaken to replicate classroom practice, thus making the entire process authentic to the students' future work (Kearney \& Perkins, 2014). Studies conducted by Azim and Khan (2012), Kerney and Perkins (2014), and Hodgman (2014) showed positive results because it was effective in encouraging student self-evaluation, reflection, and critical thinking.

The findings were in line with Saputri (2016). However, they also found that authentic assessment was difficult to apply, leading to problems. For example, a teacher decided to use a portfolio to promote authentic assessment (Hodgman, 2014). To promote it, teachers had to carefully consider their willingness before applying it (Hodgman, 2014).

Despite the weaknesses of more extended time allotment, authentic assessment could equip students for lifelong learning and promote engaged learning; one has to consider the other assessment functions in the broader scheme of things (Koh, Tan \& Ng, 2012).

The authentic assessment was claimed to have practicality regarding time, ease of use, ease of correction, facility supports, and cost required (Atmazaki, 2017). The assessment could increase the students' inquiry skills, critical thinking skills, ability in writing, and be able to measure the students' productive English skills. Hodgman (2014) explains the four essential characteristics of authentic assessment. They are performance representation, focus on the teaching and learning, prominent self-assessment component, student-work presentation.

Learners must think and actively construct evolving mental models (Collin, 2013). Not only must they interpret the information they receive and relate it to the knowledge they already have, but they must also be able to transfer it to a new context. All authentic assessments are performance assessments because they require students to construct extended responses, perform on something, or produce a product (Koh, 2017). Both process and product matter to authentic assessments, and hence formative assessment - such as open questioning, descriptive feedback, self-and peer assessments can be easily incorporated into authentic assessments.

Adnan et al. (2019) state that teachers can have good competence in the assessment if it can be conducted well. It means the practice of authentic assessment is strongly related to teachers' competencies. Teachers must have four competencies, such as pedagogical, personal, professional, and social competencies (Minister of National Education Regulation No.16 2007) in Aimah et al. (2017). Febriana and Faridi (2016) suggest that English teachers need good competencies to make effective English teaching and learning in the classroom to gain good achievement for the students. As a result, the contribution of all teaching competencies simultaneously or jointly declared significant has influenced the quality of performance in the learning process (Hakim, 2015). Teachers' pedagogical competence is the ability to manage learning, which includes planning, implementation, and evaluation of learning outcomes of learners (Rahman, 2014).

Teacher pedagogical competence had a significant influence in improving learning performance (Hakim, 2015). This competence could be seen in how teachers managed the classroom. Studies conducted by Aimah et al. (2017), Suciu and Mata (2011), and Kumalasari et al. (2017) also found how teachers' managed the classes influenced learners' comprehension in developing their competence. 
Rahman (2014) argues professional competence is competence related to the ability to master knowledge. This competence dealt with developing materials and communicating the materials and discourse aspects (Syamsinar \& Jabu, 2015). This professional development process could be seen in the theoretical knowledge, experiential learning in practice, and didactic teaching concept (Valica \& Rohn, 2013). It is in line with studies of Ilanlou and Zand (2011), Valica and Rohn (2013), and Syamsinar and Jabu (2015) that found the professional competence guaranteed students' academic achievement, teacher-student rapport, students' efficiency, improvement of students' mental health, better learning, and comprehensive knowledge (Ilanlou \& Zand, 2011).

Teachers should have professional competence (Syamsinar \& Jabu, 2015). It is important to note that the four competencies do not have the same weight.A teacher must master the knowledge before explaining the material to the students. If the teacher does not master it, he would have difficulty in explaining it.

The contribution of teacher pedagogy competence also influenced the effective English teaching in the class. It meant lower pedagogical competence realization would also influence classroom learning (Kumalasari et al., 2017). From the findings, the previous studies suggested for subsequent researchers to investigate more on pedagogical competence.

Teaching and learning cannot be separated. Teaching refers to what action teachers should take, while learning refers to what learners have to do to learn (Anton, 2015). The realization of a teacher's teaching is seen in his strategy. The most commonly applied to teach stages can be summed up as 1) warming up, 2) introducing the classroom activity, 3) implementing the plant, 4) evaluating, and 5) reflecting (Lumpkin, 2020; Post, 2011). This model shows that pedagogical and professional competencies are needed to manage the teaching stages. It means they exist before, during, and after the teaching stages.

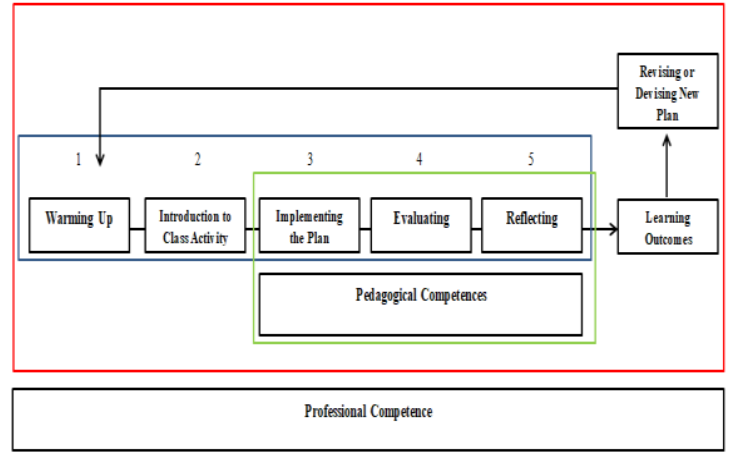

Figure 1. The Framework of Teaching, Pedagogical Competence, and Professional Competence

Pedagogical and professional competencies are the core competencies. These two competencies are getting more attention because there is a close relationship between those competencies with teachers' abilities. In this sense, the teachers are expected to implement and perform the high-quality teaching and learning process.

The teachers' performance will influence students' achievement in delivering the materials during the teaching and learning process. The teachers become the most important persons that can help and motivate students to learn more on how to improve their ability to master materials they got from the teachers, especially by doing the authentic assessment. The authentic assessment can be promoted during stages 3, 4, and 5, as shown in the framework below.

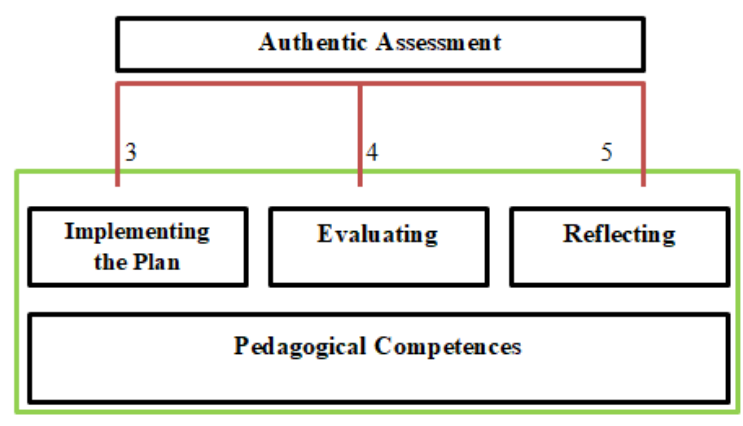

Figure 2. The Framework of Authentic Assessment Promotion

From the figures above, it is understood that both professional competence and pedagogical competencies cannot be separated. 
Pedagogical competence is part of professional competence to carry out effective teaching. Therefore, this research will use the following framework to answer the research questions. The framework is based on the previously explained theoretical framework figures and the indicators of professional competence.

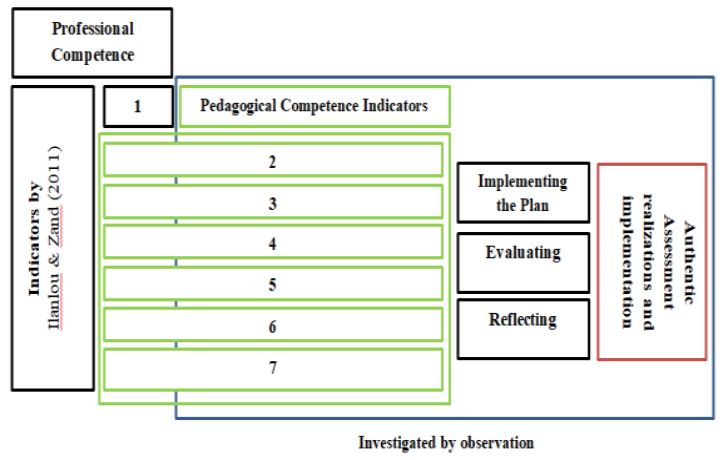

Figure 3. The Theoretical Framework of the Research

Many researchers conducted a study of teachers' competence and authentic assessment separately. Different from those previous studies, I would like to conduct a study that not only about teachers' competence but also about authentic assessment. Therefore, I will seek how teachers' pedagogical and professional competencies affect their authentic assessment practice.

This research aims to explain how teacher's pedagogical competence of English Teachers of Senior High School 1 Jepara is implemented; how teacher's professional competence of English Teachers of Senior High School 1 Jepara is implemented; the authentic assessment of English Teachers of Senior High School 1 Jepara; to describe the application of the authentic assessment type at Senior High School 1 Jepara, and to investigate the effect ofteachers' pedagogical and professional competences of English Teachers of Senior High School 1 Jepara on authentic assessment practice.

\section{METHODS}

This study investigated the effects of pedagogical and professional competencies on authentic assessment practice. In getting the information, it used qualitative research. For qualitative research, the problems had to be explored to obtain a deep understanding. A case study was conducted to obtain a deep understanding. Thus, multiple sources of data are needed, such as observation, interview, and questionnaire.

SMA N 1 Jepara was the setting of this study. It aimed to investigate and describe the effect of teachers' pedagogical and professional competencies on authentic assessment practice.

This study aims to explain the teacher's pedagogical competence on EFL, the teacher's professional competence on EFL, the authentic assessment on EFL, to describe the application of authentic assessment, and to investigate the effect ofteachers' pedagogical and professional competencies on authentic assessment practice. Additionally, the objects of this study were the teacher's pedagogical competence, the teacher's professional competence, the authentic assessment on EFL, the application of authentic assessment, and the effect of teachers' pedagogical and professional competencies on authentic assessment practice. The subjects of the study consisted of the English teachers of Public Senior High School 1 Jepara.

Several types of data would be obtained through the research process, such as classroom observation, interview, and questionnaire. The gathered data through observation were in the form of video, observation of the teacher, and notes; as to data from the interview are in the type of audio and interview transcription. The questionnaire also provided data that facilitated the researcher in collecting the information related to the focus of this study.

The first instrument for collecting the data was the observation checklist. The observation was developed based on the indicator proposed by Ilanlou and Zand (2011). The researcher conducted the observation directly during the teaching and learning process. The focused indicators of the observation were the emphasis on the consequences of learning than on its products, the emphasis on learners' selfevaluation, and their responsibility for their 
learning and also other students' learning, the opportunities for internal motivation development, the increased judgmental sources and data validity, the descriptive feedback to bring improvement and performance development, and the modulation of evaluation system with the social system of schools. The indicators were used for the questionnaire because they represented professional and pedagogical competencies and authentic assessment implementation.

The second instrument was an interview. It consisted of several questions to determine the teacher's professional competence and confirm the teacher's pedagogical competence.

The collected data from the observation would be analyzed using Miles and Huberman's model of analysis, consisting of data reduction, data display, and conclusion. Then, both questionnaires and interviews would be used to triangulate the results of the observation.

The applied data triangulation in this research is data analysis triangulation (Stefura, 2014). It meant applying more than one data analysis technique to explain and clarify the phenomena (Stefura, 2014; Thomas \& Raheem, 2020).

\section{RESULTS AND DISCUSSION}

\section{The Manifestation of the Teacher's Pedagogical Competence}

Pedagogical competence can be found during the teaching plan implementation, evaluation, and reflection. The teacher paid attention to the character education for the learners. It made the teacher design and implemented contextual teaching and learning to instill the character (Observation, 19/02/2021)

The teacher promoted it by providing relevant examples or stories for the learners. Therefore, the teacher engaged the learners to interact and prepare them to get into the lesson. The teacher did it by providing opportunities for them to ask or confirm the materials (Observation, 19/02/2021).

Sometimes, the learners did not pass the requirements due to the applied language of the teacher. Therefore, the teacher frequently switched her language, provided times for the learners to respond and comment, and clarified the responses or comments (Observation, 19/02/2021). It became even more complicated during this pandemic because sometimes the learners did not respond to the teacher.

Moreover, it was also found that the learners did not respond to the teacher's instruction to interact with each other. It made the teacher adjusted her teaching strategy, such as by ensuring them to always keep up with the class flow.

The teacher's other pedagogical competence was when the teacher connected the responses of the well-performed learners to the actual world reality. Then, the teacher used it to elicit more responses from other learners (Observation, 19/02/2021). The teacher also connected the responses or materials to the adjusted actual world reality by attaching YouTube links of certain relevant videos since they were the most up-to-date (Observation, 19/02/2021).

In this research, the learners sometimes were found to have no proper understanding of the materials. However, due to the applied authentic assessment stage, the teacher could take the responses of the well-performance learners to elicit more responses from the other learners (Observation, 19/02/2021). It showed the pedagogical competence of the teacher. The teacher did not underestimate the other learners due to no responses and did not make those responding to her the only models. The teacher used the responses from the well-performance learners to encourage other responses from the other learners.

\section{The Manifestation of the Teacher's Professional Competence}

The teacher's professional competence could be found when the teacher prepared the syllabus and lesson plan. The teacher admitted that arranging the syllabus and lesson plan was very important. The teacher made it flexible as demanded by the Educational Minister. The teacher also realized that the plan would not be 
running smoothly, so the teacher always considered the characteristics of the learners.

She also revised it when she found difficulties in applying the plan and evaluated the learners. She argued that evaluation was important to make the learners aware of their achievement and progress at each meeting.

The other professional competence of the teacher could be found when the teacher applied the appropriate media. The teacher took the appropriate learning media based on the learners' characteristics to be engaged in the learning. The teacher also prepared different teaching methods for different classes.

\section{The Authentic Assessment of English Teachers}

The teacher has practiced the authentic assessment. She argued that before the learners could proceed to the next stage, they should meet certain criteria. Unfortunately, when it came to the concrete activity of an authentic assessment system, the teacher did not have sufficient knowledge about it. The teacher mentioned the type of authentic assessment, but the teacher did have the printed form of the project.

\section{Type of the Authentic Applied Instrument}

The teacher applied the project as an authentic assessment. On the other hand, the teacher only applied the concept of authentic assessment during her teaching sequence. The teacher asked the learners to create a project and determined some criteria that learners should master before proceeding to the next learning sequence.

Unfortunately, the teacher did not provide a clear handout for the learners to do it. The teacher was aware of the authentic assessment for learning progress, but unfortunately, the learners thought they were only assessed at the end of the authentic sequence.

During the implementation of the project, the teacher only communicated the achievements, the outcomes, and the learners' learning progress (Observation, 19/02/2021). The teacher acknowledged the efforts of the learners to complete the project so that the evaluation was based on the project result. It was different from the learners' expectations. They wanted to be evaluated during the progress. They argued that the feedbacks during the progress were only encouragement. The teacher admitted it. The teacher argued the teacher had to provide appropriate feedback for the learners, so the teacher had to learn and improve.

\section{The Impacts of Teachers' Pedagogical and Professional Competencies of English Teachers toward their Authentic Assessment Practice}

The pedagogical competence could be found from how the teacher considered the needs of the learners; how the teacher acknowledged the learners' products; how the teacher encouraged the learners; how the teacher was aware of the appropriate teaching method; how the teacher communicated with the learners; and how the teacher managed the class (Observation, 19/02/2021). However, the teacher was lack of corrective feedback and reflection stages. It was since the teacher focused on the learners' strengths and provided examples as the reflection. The teacher should have provided corrective feedbacks so that learners would be aware of their incorrectness. Thus, they would revise and apply the correct ones (Shobaha, 2019; Wulandari \& Sumarwati, 2020). The corrective feedback should have also been applied while reflecting. An ideal reflection should involve five stages: exploring personal experience, understanding and appreciating new things, perceiving the concept, realizing the weaknesses, planning for future implementation, promoting improvement (Ritunga \& Rambung, 2020).

Although the teacher had already performed sufficient competencies, the teacher was lack of proper authentic assessment implementation. The teacher had excellent knowledge, but the teacher could not realize the assessment in printed form. The teacher argued that this pandemic situation adapted hindered. It was in contrast with the nature of authentic assessment that could be adjusted to the current situation during the pandemic, for example, promoting authentic assessment with an eportfolio (Misdi, 2020). This gap showed that the teacher could not continuously develop his 
academic qualification and competence based on science, technology, and art advancement (Ariawati, 2017).

The authentic assessment promoted by the teacher should provide more useful information (Hijriati, 2014). However, the teacher missed out on this one pedagogical criterion to promote authentic assessment (Observation, 19/02/2021). The teacher provided feedback, encouragement, and examples, but she did not develop critical thinking skills.

\section{The Manifestation of the Teacher's Pedagogical Competence}

The teacher's teaching could be observed from the applied teaching strategy. Based on the theoretical framework, the professional competence of a teacher also covers pedagogical competence. It means a professional teacher should carry out the plan, evaluate the teaching and learning process, and reflect on the learning.

Employing carrying out dealt with how the teacher could apply, manage, and adjust the plan. It was important because the learners had various needs. Every learner was different, and every learner might require different learning needs. According to the finding, the teacher applied contextual learning to instill character education. This action was evidence of teacher pedagogical competence. Many studies showed positive correlations between pedagogical competencies and learning outcomes; and pedagogical competence and teacher performance.

The finding of the teacher's pedagogical competence manifestation showed how the teacher promoted a specific teaching design, the CTL. Sari (2013) found a need for specific design and methods to promote character education. Contextual teaching and learning were useful for instilling character education and facilitated teachers to provide feedback and promote authentic assessment (Asrama \& Bakar, 2020; Irwandi, 2014; Sadia et al., 2013). It is also in line with the study of Berns \& Erickson (2001), Marfuah \& Febriza (2019), and Saputri et al. (2018). They found that contextual learning could facilitate authentic assessment implementation and learners' individual needs.
In this research finding, the teacher attempted to apply contextual learning to get the expected outcome, the learners' excellent characters. The teacher also did it to provide feedback and apply the authentic assessment for the learners. Therefore, the teacher could keep up with the learners' development. In this research, the teacher applied the concept of authentic assessment during her teaching sequence, but it was not maximum. The teacher asked the learners to create a project and determined some criteria that learners should master before proceeding to the next learning sequence. The findings were in line with Canning et al. (2020) about the practical difficulties of assessing this pandemic. The same finding was also found by Alamsyah et al. (2021). They found that teachers could not rigidly stick to their pre-arranged plan, but they had to adjust the strategies based on the ongoing situation.

In this research, when the learners did not understand the materials or did not respond to the teacher, the teacher would immediately switch her language. It was a realization of a teacher's pedagogical competence. This action could also make the learners indirectly evaluated themselves and asked assistance from the teacher. Unfortunately, although the teacher could provide feedback about the materials, the teacher could not do the same thing when the learners about the stages in the authentic assessment. It was because the teacher could not materialize the elements of authentic assessment into printed form. In this matter, the teacher should evaluate her teaching before evaluating the learners' learning outcome. Therefore, to improve the learning, the teacher should also improve her pedagogical competence.This finding supported Kurniawan (2020) that there was no need to be panic. It should have been a moment for both teachers and learners to create a mutual, conducive, and supportive environment for learning. The moment also made the teacher realized his role as a facilitator instead of the only learning resource (Pratama \& Rachman, 2020).

Rahman (2014) showed that teachers could improve their pedagogical competence by actively participating in the subject-teacher 
association, training, and autonomous digital learning. Therefore, teachers need to upgrade their competence to apply the authentic assessment since it is a new thing for teachers while applying the 2013 curriculum. They were important because teachers had limited time. They spent their time preparing the materials, promoting the learning, evaluating the teachinglearning, and assessing the learners' outcomes. If schools and educational institutions did not facilitate them, teachers would not determine the appropriate authentic assessment forms. This matter would lead to result disorientation, from the process orientation into product orientation assessment.

\section{The Manifestation of the Teacher's Professional Competence}

Based on the theoretical framework, this research perceived pedagogical competence as part of professional competence. The reason was the teachers' awareness about teaching and educating learners became the main job of a teacher. This research showed that the teacher prepared the syllabus and lesson plan, considered the learners' characteristics, revised the plan, and applied the appropriate media.This study was in line with Reflinda (2017). The research found that evaluation functioned to obtain information and to determine further learning processes for the learners. Rahman (2014) also argued that better and higher pedagogical competence led to higher professional competence.

Based on the learners' perspectives, they are considered to have advantages due to evaluation. They knew their weaknesses and how to improve. Thus, learners could be more productive, creative, and active (Fachri, 2018). It was because the teacher did have a score-oriented evaluation. He evaluated the learners so they could develop their understanding. The teacher attempted to connect the previous activities into a listening song activity. He wanted to check whether the learners were aware of the previous materials and could apply them or not. It was in line with Muslimah (2009) that teachers had to prepare appropriate learning media to develop learners' creativity.

\section{The Authentic Assessment of English Teacher}

In this research, the teacher had average knowledge about authentic knowledge. However, the teacher could not realize it properly. The same finding was also found in Armadeni et al. (2019) and Ani (2013). They found that teachers had an excellent understanding of authentic assessment concepts, but they could not realize it into a handout. It showed that the authentic assessment practice did not meet the expectation of the 2013 curriculum. It might also be due to the complex demand from the 2013 curriculum (Ruslan et al., 2016). Thus, it confused the teacher to create the printed version of the authentic assessment (Martika \& Zaim, 2021)

\section{Type of the Authentic Applied Instrument}

The teacher applied the project as an authentic assessment. The teacher was aware of the authentic assessment for learning progress, but unfortunately, the learners thought they were only assessed at the end of the authentic sequence. It showed that learners required clear information on what criteria they were assessed. This finding was in line with (Mursyida et al., 2020). They found that authentic assessment should have a clear printed guideline for learners so that the reports would reflect the learners' competencies.

\section{The Effect of Teachers' Pedagogical and Professional Competencies of English Teacher toward the Applied Authentic Assessment Practice}

The teacher had excellent pedagogical and professional competence. He could plan, promote, and evaluate the learning (Ariawati, 2017). The teacher had excellent knowledge, but she could not realize the assessment into printed form. This finding was also found in a previous study conducted by Fook and Sidhu (2010). They found that teachers should also have this pedagogical competence to develop critical thinking skills because it was the purpose of authentic assessment and current century skill requirement. If the teacher only provided the example as the evaluation or feedback during an 
authentic assessment implementation, the learners would not solve real-life problems (Fook \& Sidhu, 2010).

From the findings and discussions, there was one feature that the teacher should improve. The teacher missed out on one pedagogical competence and led to ambiguity during the project's authentic assessment implementation. Therefore, the teacher should realize it and keep up with the academic qualification and competence. It meant the teacher had to keep upto-date with the science and technology development, especially for learning. The teacher also had to be aware of her feedbacks. It could be seen that not each encouragement and positivetone feedbacks could improve the learners. Learners also needed corrective feedbacks moreover during the authentic assessment implementation.

\section{CONCLUSIONS}

The teacher manifested her pedagogical competence into the plan implementation, evaluation, and reflection from the findings. However, the teacher missed out on two components of pedagogical competence. The teacher could realize and apply what the teacher planned in the lesson plan on professional competence. The teacher was aware that the lesson plan was crucial for learning activities. The teacher also applied the teaching phases systematically from the beginning, the main teaching activity, the closing of the class, and the evaluation.

This research was limited to the applied pedagogical model. It also focused on how the teacher carried out the plan, evaluated, and administered the authentic assessment. There might have been many pedagogical competence realizations, such as teachers' empathy, English diction awareness, etc. The other limitation was the instrument applied for this research, especially the observation checklist. The observation checklist was designed by me, the researcher, without being tested in terms of validity. Thus, future researchers should have a validated instrument to collect the data.

\section{REFERENCES}

Adnan, Suwandi S., Nurkamto J., \&Setiawan B. (2019). Teacher competence in authentic and integrative assessment in Indonesian language learning. International Journal of Instruction, 12(1), 701-716.

Aimah, S., Ifadah, M., \& Bharati, D. A. L. (2017). Building teacher's pedagogical competence and teaching improvement through lesson study. Arab World English Journal, 8(1), 66-78.

Alamsyah, Lubis, R. R., \& Elfiana, U. (2021). Learning design during the COVID-19 pandemic in STAI Sumatera Medan (study on adjustment of learning outcomes). Proceeding International Seminar on Islamic Studies, 2, 215221.http://jurnal.umsu.ac.id/index.php/ insis/article/view/6245/pdf_163

Ani, Y. (2013). Penilaian autentik dalam Kurikulum 2013. Seminar Nasional Implementasi Kurikulum 2013, November, 746-749.

Anton, S. (2015). Pendekatan parade untuk meningkatkan aktivitas dan hasil belajar peserta didik tentang materi sistem pemerintahan melalui pemanfaatan media voucher pada kelas xii IPS 2 SMA Negeri 1 Lasem. Jurnal Ilmiah CIVIS, V(2), 843854

Ariawati, K. N. (2017). Bagaimana cara menjadi guru profesional dalam meningkatkan hasil belajar siswa dan memperbaiki pendidikan di Indonesia.https://www.researchgate.net/ publication/315099734_BAGAIMANA_ CARA_MENJADI_GURU_PROFESIO NAL_DALAM_MENINGKATKAN_H ASIL_BELAJAR_SISWA_DAN_MEM PERBAIKI_PENDIDIKAN_DI_INDO NESIA

Armadeni, Roza, M., \& Arief, A. (2019). Kendala pendidik dalam menerapkan penilaian autentik pada kurikulum 2013 di MIN Kecamatan Bayang Kab Pesisir Selatan. Jurnal Tarbiyah Al-Awlad, 9(1), 63-76. 
Asrama, Y., \& Bakar, A. (2020). Implementasi nilai-nilai Pancasila dengan pendekatan Contextual Teaching Learning untuk menumbuhkan karakter mahasiswa. JOEAI (Journal of Educational and Instruction), 3(1), 1-13.

Atmazaki. (2018). Authentic assessment in Indonesian language learning. Advances in Social Science, Education, and Humanities Research (ASSEHR), 148.

Azim, S., \& Khan, M. (2012). Authentic assessment: An instructional tool to enhance students learning. Academic Research International, 2(3), 314-320.

Berns, R. G., \& Erickson, P. M. (2001). Contextual teaching and learning: preparing students for the new economy. In The Highlight Zone Research (Issue 5, pp. 1-8). ERIC.

Canning, C. A., Freeman, K. J., Curran, I., \& Boursicot, K. (2020). Managing the COVID-19 risk: the practicalities of delivering high stakes OSCEs during a pandemic. MedEdPublish, 9(1), 1-7.

Collins R. (2013). Authentic assessment: assessment for learning. Curriculum and Leadership Journal, 11 (7).

Fachri, M. (2018). Urgensi evaluasi pembelajaran dalam pendidikan urgensi evaluasi pembelajaran alam pendidikan.Edureligia; Jurnal Pendidikan Agama Islam, 2(1), 64-68.

Febriana, E. \& Faridi, A. (2016). The junior high school English teachers' fulfillment of the four competencies. English Education Journal, 6(1), 31-38.

Fook, C. Y., \& Sidhu, G. K. (2010). Authentic assessment and pedagogical strategies in Higher Education. Journal of Social Science, 6(2), 153-161.

Hakim, A. (2015). The contribution of teacher's competence (pedagogical, personality, professional competence, and social) on the performance of learning. The International Journal of Engineering And Science, 4(2), 1-12.

Hodgman, M. R. (2014). Using authentic assessments to better facilitate teaching and learning: the case for student portfolios. Journal of Studies in Education, 4(3), 59-65.

Hijriati, H. (2014). Authentic assessment and the implication to students' self-esteem in teaching English at Senior High School. The 61st TEFLIN International Conference, 1155-1158.

Ilanlou, M., \& Zand, M. (2011). Professional competencies of teachers and the qualitative evaluation. Procedia - Social and Behavioral Sciences, 29, 1143-1150.

Irwandi. (2014). Balancing between head and heart: a strategy of character education in ELT. Proceeding of the Third International Seminar on Languages and Art, 1993, 261266.

Kearney, S. P., \& Perkins, T. (2014). Engaging students through assessment: the success and limitations of the ASPAL (Authentic Self and Peer Assessment for Learning) model. Journal of University Teaching and Learning Practice, 11(3), 1-13.

Koh, K. H. (2017). Authentic Assessment. https://doi.org/10.1093/acrefore/97801 90264093.013 .22

Koh, K.H., Tan, C., Ng, P.T. (2012). Creating thinking schools through authentic assessment: the case in Singapore.EducAsseEvalAcc, 24.

Kumalasari, S.P., Setiawan, B., Sumarlam. (2017). Pedagogical competence of Indonesia teachers viewed from the anecdote writing lesson plan. Lingua Didaktika, 11 (2), 146-156. DOI:

Kurniawan, H. (2020). The role of teachers and students in dealing with education in the pandemic time of COVID-19. Sosioedukasi : Jurnal Ilmiah Ilmu Pendidikan Dan Sosial, 9(2), 92-99.

Lumpkin, A. (2020). Effective teaching and learning - a five-step process. Journal of Education and Culture Studies, 4(3), p32.

Marfuah, A., \& Febriza, F. (2019). Penilaian autentik pada pembelajaran Pendidikan Agama Islam (PAI) di sekolah dan perguruan tinggi. Fondatia: Jurnal Pendidikan Dasaar, 3(2), 35-58. 
Martika, S. E., \& Zaim, M. (2021). The implementation of authentic assessment on reading comprehension of the tenthgrade students of SMAN 8 Padang. Journal of English Language Teaching, 10(1), 129137.

Misdi, M. (2020). E-portfolio as an authentic learning assessment in response to COVID-19 outbreak in Indonesian Higher Education: toward critical student-writers. Research and Innovation in Language Learning, 3(2), 158.

Mursyida, I. T., Faridi, A., \& Suwandi. (2020). English teachers' perception and implementation of authentic assessment for speaking based on 2013 curriculum. English Education Journal, 10(3), 273-281.

Muslimah, U. N. (2009). Teacher professionalism on the developing children creativity (sociology of education perspective). REGISTER, 2(1), 24-34.

Post, P. A. (2011). Trial by hire: the seven stages of learning to teach in higher education. Contemporary Issues in Education Research (CIER), 4(12), 25.

Pratama, H. F., \& Rachman, A. K. (2020). Pengoptimalan kreativitas guru bahasa Indonesia di masa pendemi COVID-19. Prosiding Seminar Nasional IKIP Budi Utomo, 314-323.

Rahman, M. H. (2014). Professional competence, pedagogical competence, and the performance of junior high school science teachers. Journal of Education and Practice, 5(9), 75-80.

Reflinda. (2017). Purpose, function, and principles of language learning evaluation. Jurnal Vision, 11(11), 1-15.

Ritunga, I., \& Rambung, E. (2020). Reflection to guide medical students' self-introspection and development: a qualitative report. Jurnal Pendidikan Kedokteran Indonesia: The Indonesian Journal of Medical Education, $9(1), 52$.

Ruslan, Fauziah, T., \& Alawiyah, T. (2016). Kendala guru dalam menerapkan penilaian autentik di SD Kabupaten Pidie.
Jurnal Ilmiah Mahasiswa Pendidikan Guru Sekolah Dasar, 1(1), 147-157.

Sadia, I. W., Arnyana, I. B. P., \& Muderawan, I. W. (2013). Model pendidikan karakter terintegrasi pembelajaran sains. JPI (Jurnal Pendidikan Indonesia), 2(2), 209-220.

Saputri, L. A. D. E. (2016). The implementation of authentic assessment to measure students' English productive skills based on the 2013 curriculum. UNNES.

Saputri, I., Nurkamto, J., \& Wahyuni, D. S. (2018). The implementation of authentic assessment in English language teaching. English Education Journal2, 6(3).

Sari, N. (2013). The importance of teaching moral values to the students. Journal of English and Education, 1(1), 154-162.

Shobaha, S. (2019). The implementation of oral corrective feedback in EFL classroom. LangEdu Journal.

Stefura, G. (2014). Using methodological Triangulation to study the individual Compliance Behaviour towards Income Reporting. SEA - Practical Application of Science, II(03), 582-587.

Suciu, A., \& Mata, L. (2011).Pedagogical competencies- key to efficient education. International Online Journal of Education Sciences, 3(2), 411-423.

Syamsinar\&Jabu, B. (2015). the problems in professional competence in teaching English subjects at vocational high schools.ELT Worldwide, 2 (2).

Thomas, O. O., \& Raheem, O. L. (2020). Triangulation method in management sciences research. Annals of the University of Craiova: Economic Science Series, 1(48), 141154.

Valica, M., \& Rohn, T. (2013). Development of the professional competence in the ethics teachers. Procedia - Social and Behavioral Sciences, 106, 865-872.

Wulandari, A. P., \& Sumarwati. (2020). Pemberian corrective feedback dalam pembimbingan menulis karya ilmiah siswa SMA. Pena: Jurnal Pendidikan Bahasa Dan Sastra, 9(2). 